UDC 811

DOI https://doi.org/10.32838/2710-4656/2021.4-2/24

Babayeva Nigar Ogtay

Baku Slavic University

\title{
THE ROLE OF INFORMATION STRUCTURE IN THE TRANSLATION OF NEWS
}

There are various lexical and grammatical devices which can operate in news articles to distribute information within this genre of discourse. These linguistic devices can offer translators rich information on the grammatical and stylistic choices of the author(s) of the original text and how they change depending on pragmatic and cognitive perspectives of all participants in translative discourse, especially among various groups of receivers. On the other hand, the translator adds his/her own preferences in the text of translation opening the road to subjectivity in translative discourse. Thus, the translator as a receiver and a sender is the core element of the research and this study is some sort of the translator's vision of the role of information structure in translative discourse. In this connection, the paper explores certain ways in which the translator rebuilds information structure of the original news texts in the context of the issues that arise during their translation into Azerbaijani and Russian languages. The methods of comparative and contextual analysis have been used for the study of the pieces of the original texts selected from 15 news articles published by the news agencies (Reuter, AP), newspapers (Daily Telegraph, Financial Times), TV-s (BBC, CNN), the sites (Buzz Feed) and the texts of translation made by the author.

Thus, to function appropriately in discourse text must satisfy the characteristic requirements of certain text type, which may be very different from those of other text types. In this regard an ideal text type for our study is news which completely depends on the pragmatic intention of the sender in discourse and thus is communicatively very dynamic.

Thus, all these examples clearly show the big potential of the word order in news text. Thanks to its change, communicatively and emotionally important part of the text is highlighted. Such kind of change relates with the inversion of statistically regular sequence of elements. Inversion highlights the element, which stands in untraditional position and thus gives additional communicative and emotional impulse to the whole text.

Key words: information structure, news articles, translative discourse, subjectivity, intention, implicit meaning.

Linguistics has made several uses of information both in a general sense, and, as formulated in the statistical terms, derived from the theory of communication. In its general sense, this fundamental concept is used by several linguists (M. A. K. Halliday, W. Chafe, etc.) as a basis for a theoretical account of the structure of messages. In this regard we have to focus on the difference between written and spoken communication. Most of us are aware of the way in which we structure large pieces of information in writing as it is a planned speech and we are encouraged to plan what we are going to write about, paragraph by paragraph. Spoken communication is more complex due to the fact that it is rarely carefully planned and mostly totally spontaneous.

But in both cases the way information is structured during the process of communication is very important. When we deliver message to a receiver, whether orally or in writing, we instinctively impose a structure in our speech and try to organize what we send in a way that will make it easier for a receiver to understand. Most of us are aware of the way in which we structure large parts of information and when we study language, we can see that we do subconsciously impose a structure on our written or oral speech as part of the act of communication. It is postulated that speech can be seen as displaying the information structure, encoding the importance of the elements in any message with formally identifiable units of information. Linguistic and extra-linguistic devices provide the main signal for such units.

We support the view on the importance of the opposition of new and old information [10] for text and discourse perspectives and we also agree with Foley, who [8, p. 1678] considers the information structure of linguistic constructions as the relatively marked coding of the elements of the structure. 
In fact, the sender of text is free to use any linguistic device for this coding of the elements depending on his/her pragmatic intention and capacity for options. It is the issue of "choice" which was well studied in linguistics [11;9]. In different types of text different factors impose limitations on this choice. Enkvist suggests that "there is a set of principles or parameters governing textual form, and these principles or parameters can be differently weighted, and thus get different priorities in different text types" [6, p 378]. For example, in the newspaper text, the grammatical correctness of syntax may sometimes have to yield to the principles of information dynamics, in particular in terms of word order.

Various lexical and grammatical linguistic devices are used to organize news text. These linguistic devices play major role in the construction of information structure in news discourse, which naturally come into prominence during translation [2; 4]. Since any order of the distribution of information in text should be reflected in the translation text, the translator always tries to convey the intention of the original sender as relevant as possible. But we have also to bear in mind that during communication text acquires its own intention [5] and the translator as a receiver and a sender cannot and should not violate this "rule". In addition, the translator should also think about the mental patterns in discourse. Discourse analysis cannot be carried out ignoring the mental patterns because they are real basics for choosing necessary communicative information for such strategic purposes as the construction of information structure.

As discourses are traditionally grouped as institutional and individual, we can identify the translative discourse [15] as a specific combination of institutional and individual discourses, which is obviously a subjective process [14]. And the translator, who is the most important participant of the translative discourse, defines this subjectivity.

1. Translator and grammatical elements

The text of translation is organized in line with the pragmatic intentions of both senders (the translator and the sender of the original text) and the cognitive abilities of bothreceivers (the translator and the receiver of the text of translation). Therefore, the translator first has to deal with the intention of the sender of the original text. This section focuses on the issue how translator manages to reflect the intention of the sender in the text of translation. The realization of the intention of the sender is true in the efforts to solve the problem of equivalency in translation through focusing on new or important part of the message delivered via text $[7 ; 2 ; 3]$.
The new information in English is often signaled by the particles, indefinite article, particles, time adverbs, determiners, the words like one or some. The old information is signaled by the definite article, personal and demonstrative pronouns a determiner. The use of all these grammatical elements and phenomena is motivated by the pragmatic intentions of a sender. Various particles can indicate the importance of any part of a sentence thus imposing communicative dynamism [13; 12]:

1) Only one in four older Britons wants the Church of England to remain the country's official religion, according to research that indicates a decline in belief among the over-50s (The Daily Telegraph, January, 2, 2009, p.11).

2) Only 44 per cent of the 23,000 convicted were locked up by the courts (Sun, July 13, 2011, p.13).

When the news producer constructs text, he/she thinks about what kind of information to supply first and how to do it. W. Chafe suggests that for normal English sentence theme comes first (Chafe, 1971). But if new or important information should be focused then the above-mentioned rheme signals are commonly used. With the instruments given above, we will try to analyze some sentences from the newspaper texts to show how and where these grammatical and lexical elements are used to highlight new or important information. The translator must highlight the same dynamism in the texts of translation:

1) 50 yaşdan yuxarı insanlar arasında dini inancın azaldığını göstərən araşdırmalara görə, yalnız hər dörd britaniyalidan biri İngiltərə kilsəsinin ölkənin rəsmi dini olaraq qalmasını istəyir. 2) 23.000 məhkumun yalnız 44 faizi məhkəmələr tərəfindən həbs edildi.

Indefinite article helps to identify an object or an event as a new one with high degree of functional contribution:

3) A Gunman Opened Fire during A Wedding At A Church in New Hampshire.

Buzz Feed News (12.10. 2019); 4) CNN August 5, 2019.

A gunman who wore a mask, bulletproof vest and hearing protection was killed by police within 30 seconds of opening fire on Sunday in a popular nightlife district in downtown Dayton, Ohio, authorities said.

The role of the indefinite article $A$ used with the word gunman in both examples is obvious. We have to see the same dynamism in the texts of translation:

3) NyuHempşirda kilsado toy zamanı bir silahlı şaxs atoş açdl.

4) Hakimiyyat orqanları ABŞ-ın Ohayo ştatının Deyton şaharinin markazindəki gecə hayatı ila maşhur 
olan bölgasində bazar günü maskall, güllə keçirməz jilet geyinmiş va eşitma mühafizasi olan bir silahl şaxsin atzş açdıqdan 30 saniya sonra polis tarafindan öldürüldüyü bildirildi.

The element one has the similar function:

5) One resident said she was not even aware that Ms. Harris had a baby son (The Times, January, 2, 2009, p. 20)

The translator can easily deliver the same message in the Azerbaijani text due to the availability of this element in this language:

5) Sakinlardən biri bildirdi ki, onun Cənab Harrisin balaca oğlu olduğundan haç xeberi yox idi.

Some linguists believe that the time adverbs like now also deliver new information in sentence (Quirk, etc. 1985):

6) Attention will now focus on the fate of other nominees to the commission who were criticized in hearings (International Herald Tribune, January 20, 2010, p. 3).

And:

7) Researchers have now found that the Tami flu-resistant strain is more likely to cause potentially deadly complications than the normal HINI virus (The Daily Telegraph, January, 2, 2009, p. 1).

The time adverb now helps to the receiver to focus attention on the fact of introducing new stage in the flow of thought. The text of translation is expected to reflect the same information structure:

6) Indi diqqat dinlamalarda tanqid olunan komissiyanin digar namizadlarinin taleyina yönaldilacak

And: 7) Tadqiqatçılar indi müqavimətli növ olan Tami qripinin normal HINI virusundan daha çox ölümcül fosadlara yol açdıqını aşkar etdilar

Thus, the particles, the articles, the adverbs and other above-mentioned grammatical elements mark something important, which is very important factor in the process of translation. Traditionally, the information structure of text in English reflects the movement of idea from known to unknown (Chafe 1971, etc.). At the same time, the traditional word order (SVO) is usually observed in the English news texts as seen below:

8) UK PM sends EU unsigned letter asking for Brexit delay (Reuters, 20 October 2019).

And: 9) Bernie Sanders draws thousands to rally in New York in comeback from heart attack (Reuters, 20 October 2019).

These examples illustrate how information structure of text is constructed in line with the traditional rules of English word order (SVO) based on the movement of idea from known to unknown.
The information distributed through the word order is reflected in the translation text by different degree of fullness. Another important issue here is the typological difference between the languages (for instance, the typology of the basic word order in the English and the Azerbaijani languages differs as the Azerbaijani as Turkish is the verb-final language). It is obvious that during translation the differences in the sequence in the original and translation texts require changes in linear order of elements:

8) Böyük Britaniyanın BaşNaziri Avropa Birliyinə Brexit-in ertələnməsini xahiş edən imzalanmamış məktub göndərmişdir.

The first text of translation begins with the subject Böyük Britaniyanın Baş Naziri that reflects the same word order as in the original text. The difference is in the position of the verb. It is actually in line with the information structure that is typical for Azerbaijani texts. Meanwhile, the translation of the second original text requires a different approach. As a result of the differences of word order rules and the ways how information structures are constructed, more serious transformation is felt necessary as seen below

9) Infarkt xəstaliyindən să̆almış Berni Sanders minlarla insanın NyuYorkda keçirdiyi mitinqa galmasina nail olmuşdur.

The subject Berni Sanders comes in the middle position, which reflects that the subject first order in the Azerbaijani sentence is not always possible and there are some other alternative ways how to construct the similar information structure.

The author(s) of news in English have also the alternative ways how to distribute information in text and thus to construct information structure. But, sometimes this way is not in line with the traditional grammatical rules as seen in the following pieces of news texts:

10) After five years of growth, the collective wealth of the world's billionaires dropped by $4.3 \%$, or $\$ 388$ billion, according to a new report from Swiss bank UBS and auditing firm PwC. By the end of the year, there were 57 fewer global billionaires, for a total of 2.101 worldwide (CNN Business, 8 November 2019).

And: 11) A spate of surveys have reflected optimism among executives and investors about the prospects of Mr Trump delivering on tax cuts, looser regulation and infrastructure projects. In January, a survey of corporate optimism by the National Federation of Independent Business rocketed to its highest reading since 2004 and has lost little ground. (Financial Times, 29 April/30 April 2017, p. 1). 
The original text clearly reflects how communicative dynamism is strengthened by the inverting of the traditional word order in English. It is intriguing how the translator deals under these circumstances. One scenario is: if any component of sentence is untraditionally put at the head of the sentence in the original text, this effective procedure must be maintained in the translation text. The translator can reach the same effect by changing word order in the Azerbaijani text (Abdullayev, 1984, etc.). In fact, the goal in both translation texts is to maintain the communicative intention of the author(s) of the original text. In order to achieve this goal, the translator should look for the available instruments in the respective language such as dividing one sentence into two or other alternatives as seen below:

10) Beş il arzindo artımdan sonra dünya milyarderlarinin birga varidatı $4.3 \%$ va yaxud 388 milyard ABŞ dolları azalmışdır. Bu barado Isveçro bankı UBS va audit şirkati PwC-in yeni hesabatında deyilir.

And: 11) Bir çox sorğular biznes idaraçilari vo sormayzdarlar arasindac-b Trampin vergilari azaldacağ yumşaldacağıvo infrastruktur layihalorina başlayacağ ${ }_{l}$ perspektivlorindon qaynaqlanan nikbinliyi aks etdirir. Yanvarda, Müstaqil Biznesin Milli Federasiyasının keçirdiyi korporativ nikbinlik sorğusu 2004-cü ildan bari an yüksak oxunuş səviyyasina çatmış va sonradan bir az zaiflamişdir.

The translator can also look for an alternative more rule-based scenario, which does not necessarily reflect the same communicative dynamism. For example:

10) İsveçra bankı UBS va audit şirkati $P w C$-in yeni hesabatına asasan, beş il orzində artımdan sonra dünya milyarderlarinin birga varidatı $4.3 \%$ vo yaxud 388 milyard $A B S ̧$ dolları azalmışdır. İlin sonunadək, dünyada milyarderlarin sayı 57 nəfər azalaraq ümumilikdə 2,101 nəfər olmuşdur.

And: 11) Bir çox sorğular biznes idaraçilari va sarmayadarlar arasinda $c$-b Trampin vergilari azaldacă̆ı, maliyya qayda-qanunların yumşaldacağ vo infrastruktur layihalorino başlayacağ perspektivlorindon qaynaqlanan nikbinliyi aks etdirir. Müstaqil Biznesin Milli Federasiyasinin yanvarda keçirdiyi korporativ nikbinlik sorğusu 2004-cü ildon bari an yüksak oxunuş səviyyasina çatmış va sonradan bir az zaiflamişdir.

According to the traditional grammars, if an English sentence contains more than one adverbial then time adverbial is used in postposition. This rule is quite common in news texts: 12) The October
17-18 opinion poll found that 21\% of Democrats and independents said they would vote for Biden in state wide nominating contests that begin next year, up 3 percentage points from a similar poll that was conducted at the end of September (Reuters, 20 October 2019).

The time adverbial at the end of September plays a very important role in this news discourse in terms of navigating the audience. The translator should take into consideration this function of the time adverbial and try to deliver it in the text of translation: 12) Namizadlarin irali sürülmasi prosedurunun galon il başlayacă̆ prezident seçkilari marafonu çarçivasinda 17-18 oktyabrda keçirilmişray sorğularında ölkaboyu demokrat va müstaqillarin 21\%-i Baydena sas veracəklarini bildirmişlar. Bu Sentyabrın sonunda keçirilmiş analoji sorğudakı naticədən 3 faiz çoxdur.

But this order is often inverted in the newspaper texts as the bearer of information in such type is not time adverbial, rather place adverbial. In this case place adverbial includes some word groups and it moves to postposition. For example:

13) BBC Sport. 24 November 2019

Manager Jurgen Klopp says he has "no problem that Liverpool weren't brilliant" during their hardfought win at Crystal Palace.

14) Beijing (Reuters). The United States is the world's biggest source of instability and its politicians are going around the world baselessly smearing China, the Chinese government's top diplomat said on Saturday in a stinging attack at a G20 meeting in Japan. 24 November 2019.

The translator has also to focus on the position of the place adverbial in the Azerbaijani text moving it to the preposition as seen below:

13) Crystal Palace-da keçirilmiş vaçatin qalaba ila naticalanmiş oyunda Baş maşqçi Yurqen Klopp "Liverpulun ala oyun nümayiş etdirmamasinin problem olmadığını" bildirmişdir.

And: 14) Yaponiyada keçirilmiş iqtisadi cəhətdən an inkişaf etmiş 20 ölkadan ibarat Qrupun şənba günü keçirilmiş görü̧̧ünda Çinli diplomat kaskin hücum tarzinda Birlaşmiş Ştatların dünyanın an böyük qeyrisabitlik mənbəyi olduğunu va siyasatçilarinin dünyanı gazərək asassız şəkildə Çinə həqarət yağdırdıqlarını bildirmişdir.

It should be noted that one and the same message can be conveyed through the texts of the different structural types. A big message is conveyed through the texts composed of several coordinating, subordinating and simple sentences. In all these occasions the difference between the types of texts 
implies additional information about stylistic or emotional features of the news. Thus, for the style of the English news texts and, in general, media texts, complex sentences with several subordinates, which cover different ideas, are common. The trend of usage of such constructions in the news texts in English can be accounted for the main functions of the news articles to inform the reader and to form his/her opinion about the message conveyed via newspaper.

Although relatively strict word order in English plays an important role to deliver the message in news, certain grammatical constructions such as it is, which can be used emphatically in order to highlight the communicative dynamism in news texts. For example:

15) 21 November $2019 \mathrm{CNN}$.

It was Friday, November 15, three days after Venice suffered the second worst flooding in its history.

This news text is characterized by the introducing important information via the construction It was Friday, November 15. The translator can deliver this information structure using the relevant linguistic devices available in Azerbaijani as seen below: 15) Bu, Venesiyada baş vermiş tarixdo on falakatli ikinci daşqindan ü̧ gün sonra15 noyabr cüma günü idi.

The translator can fill the gap due to the lack of the similar construction in Azerbaijani by moving the key temporal markers 15 noyabr cümə günü idito the postposition. Due to its diverse functions in text, word order in the original text is reflected in the translation text only in case of similarity of information conveyed by certain order of words in both texts. Under this circumstance necessary degree of equivalency is reached by the analogical distribution of elements in the translation text. Meanwhile, in many cases the word order in the original and translation texts differs.

Some grammatical elements (particles, articles, adverbs, etc.) and devices (inversion)are common tools in English news texts to perform diverse communicative functions. The information conveyed by those devices through the type and the structure of the original news text is reflected in the translation text by different degree of fullness. But, in all occasions, this information covers only a part of the whole content of the original text due to the obvious existence of certain amount of implicit meaning and the general equivalence between the original text in English and the text of translation in Azerbaijani language depends, in large extent, on the fullness of the reflection of information in the translation text. Serving as the signals for the receiver of news text these linguistic devices have different communicative weights. Given human ability to keep certain amount of information in memory these elements eventually perform strong pragmatic and cognitive functions to ensure global connexity in discourse.

\section{References:}

1. Абдуллаев К. М. Теоретические проблемы синтаксиса азербайджанского языка : дис. ... докт. филол. наук. Баку, 1984.

2. Комиссаров В. Н. Смысловая стратификация текста как переводческая проблема. В кн. Текст и перевод, Москва : Наука, 1988, с. 6-17.

3. Черняховская Л. А. Информационная структура текста как объект перевода. В кн. Текст и перевод, Москва : Наука, 198, с. 17-24.

4. Blum-Kulka S. "Shifts of Cohesion and Coherence in Translation". In Lawrence Venuti (ed.). The Translation Studies Reader. London : Routledge, 2001, p. 98-312.

5. Eco U. Confessions of a young novelist. Cambridge, Massachusetts : Harvard University Press, 2011.

6. Enkvist N. From Text to Interpretability: A. Contribution to the Discussion of Basic Terms in Text linguistics. Connexity and Coherence: Analysis of Text and Discourse / Ed. By W. Heydrich. Berlin, New York : Mouton de Gruyter, 1989, pp. 369-382.

7. Firbas J. Interplay in functional sentence perspective. In the Prague School of Linguistics and Language Teaching, London : Longman, 1972.

8. Foley W. A. Information structure. The encyclopedia of language and linguistics. Oxford : Oxford University Press, V. 3. 1994, pp. 1678-1685.

9. Fontaine L. Introduction: choice in contemporary systemic functional theory. In: Systemic Functional Linguistics Exploring Choice / Ed. by L. Fontaine, T. Bartlett and G. O'Grady. Cambridge : Cambridge University Press. 2013, pp. 1-11

10. Givon. Syntax: A Functional-Typological Introduction. Vol. 2, Amsterdam : Benjamins, 1990.

11. Halliday M. A. K. Meaning as choice. In: Systemic Functional Linguistics Exploring Choice / Ed. by L. Fontaine, T. Bartlett and G. O'Grady. Cambridge : Cambridge University Press. 2013, pp. 15-36.

12. Klammer Th., Schulz M., Volpe M. Analyzing English Grammar. London : Longman, 2007.

13. Konig E. The meaning of focus particles. A comparative perspective. London; New York, 1991.

14. Mammadov A., Ziyadova L. Subjectivity of discourse and translation: functional-cognitive approach. Asia-Pacific Translation and Intercultural Studies, Vol. 3, No. 3, Oxon : Routledge, 2016, pp. 223-234.

15. Pym A. Method in Translation History. Manchester: St. Jerome Publishing, 1998. 
Бабаєва Н. О. РОЛЬ СТРУКТУРИ ІНФОРМАЦІЇ В ПЕРЕКЛАДІ НОВИН

С різні лексичні та граматичні засоби, які можуть діяти в новинних статтях для поширення інформацї в рамках иього жанру дискурсу. Ці мовні засоби можуть запропонувати перекладачам багату інформацію про граматичний та стилістичний вибір автора (авторів) оригінального тексту та про те, як вони змінюються залежно від прагматичних та когнітивних точок зору всіх учасників перекладащького дискурсу, особливо серед різних груп одержувачів. 3 іншого боку, перекладач додає власні переваги в тексті перекладу, відкриваючи шлях до суб'єктивності в перекладацькому дискурсі. Таким чином, перекладач як одержувач і відправник є основним елементом дослідження, $i$ ие дослідження є деяким баченням перекладача щьоо ролі інформачійної структури в перекладацькому дискурсі. У зв'язку з иим у статті досліджуються певні шляхи, за якими перекладач відновлює інформаційну структуру оригінальних текстів новин у контексті питань, щя виникають під час їх перекладу на азербайджанську та російську мови. Методи порівняльного та контекстного аналізу були використані для вивчення фрагментів оригінальних текстів, відібраних із 15 статей новин, опублікованих інформачійними агентствами (Reuter, AP), газетами (Daily Telegraph, Financial Times), телеканалами (BBC,$C N N)$, сайтами (Buzz Feеd) та тексти перекладу, зроблені автором.

Отже, щоб належним чином функціонувати в тексті дискурсу, слід задовольняти характерні вимоги певного типу тексту, які можуть сильно відрізнятися від вимог інших типів тексту. У иьому відношенні ідеальним текстовим типом для нашого дослідження є новини, які повністю залежать від прагматичного наміру відправника в дискурсі, отже, комунікативно дуже динамічні.

Таким чином, усі иі приклади в роботі чітко демонструють великий потенціал порядку слів у тексті новин. Завдяки його змінам виділено комунікативно та емоційно важливу частину тексту. Така зміна пов'язана з інверсією статистично регулярної послідовності елементів. Інверсія виділяс елемент, який стоїть у нетрадиџійному положенні і тим самим надає додатковий комунікативний та емоційний імпульс усьому тексту.

Ключові слова: інформачійна структура, статті новин, перекладний дискурс, суб'єктивність, намір, неявний зміст. 